\title{
PENGARUH RESIRKULASI LINDI SECARA ANAEROBIK PADA SAMPAH SEGAR DAN SAMPAH TPA BATU LAYANG, PONTIANAK
}

\author{
Dwi Farastika' ${ }^{1)}$ Isna Apriani ${ }^{1}$ Ulli Kadaria ${ }^{1)}$ \\ 1) Program Studi Teknik Lingkungan Jurusan Teknik Sipil Fakultas Teknik Universitas Tanjungpura, Pontianak \\ Email : dwifarastika@gmail.com
}

\begin{abstract}
ABSTRAK
TPA Batu Layang, Pontianak adalah salah satu TPA di Indonesia yang beroperasi dengan sistem open dumping. Salah satu kelemahan sistem ini yaitu rendahnya tingkat reduksi sampah pada TPA. Sementara itu, nilai BOD dan COD lindi TPA Batu Layang belum memenuhi standar baku mutu yang berlaku. Komposisi sampah TPA Batu Layang didominasi oleh sampah organik, sehingga pengolahan biologis sesuai untuk diterapkan. Resirkulasi lindi adalah jenis pengolahan biologis yang telah diketahui dapat menurunkan kandungan organik pada lindi, mempercepat proses biodegradasi sampah, serta memperbesar volume biogas yang dihasilkan. Penelitian ini bertujuan untuk mengetahui pengaruh resirkulasi lindi pada sampah segar dan sampah TPA terhadap kualitas effluent lindi, laju degradasi sampah, dan volume biogas yang dihasilkan. Sehingga akan diketahui jenis sampah yang tepat untuk aplikasi resirkulasi lindi di TPA. Resirkulasi lindi dilakukan pada 2 buah bioreaktor dengan debit resirkulasi lindi sebesar 23,4 I/hari selama 28 hari. Lindi ditempatkan di wadah stok lindi untuk dialirkan kedalam bioreaktor sampah dalam waktu satu hari. Lindi yang keluar dari bioreaktor sampah ditampung di bak penampung sebelum ditempatkan kembali secara manual di wadah stok lindi. Hasil penelitian menunjukkan nilai BOD dan COD lindi yang semula 203,38 mg/l dan 986,7 mg/l pada akhir penelitian turun menjadi 42,03 $\mathrm{mg} / \mathrm{l}$ dan $285,7 \mathrm{mg} / \mathrm{l}$ setelah diresirkulasi pada sampah segar, dan turun menjadi 50,67 mg/l dan $300 \mathrm{mg} / \mathrm{l}$ setelah diresirkulasikan pada sampah TPA. Pada akhir penelitian, persentase penurunan nilai BOD dan COD lindi pada reaktor berisi sampah segar (R1) sebesar 79,33\% dan 71,04\% sedangkan pada reaktor berisi sampah TPA (R2) sebesar 75,09\% dan 69,50\%. Namun, penurunan BOD dan COD lindi R2 sebesar $72 \%$ dan $60 \%$ terjadi pada minggu pertama perlakuan resirkulasi lindi. Laju degradasi sampah pada R1 sebesar 0,6768/minggu sedangkan pada R2 sebesar 0,0784 /minggu. Volume biogas pada R1 mulai terukur pada hari ke-14 hingga akhir penelitian pada hari ke-28 dengan volume maksimum dicapai pada hari terakhir sebesar $163 \mathrm{ml}$. Pada R2 volume biogas tidak terukur selama masa penelitian.
\end{abstract}

Kata Kunci : resirkulasi lindi, degradasi anaerob, laju degradasi sampah

\begin{abstract}
Batu Layang landfill site, Pontianak is one landfill sites in Indonesia that applies open dumping system. One of the disadvantages of this system is the low rates of landfill waste reduction. Meanwhile, BOD and COD value of leachate from Batu Layang landfill site does not meet the applicable quality standards yet. Waste composition in Batu Layang landfill site is known to be dominated by organic waste. Therefore, biological treatment is suitable to be applied. Leachate recirculation is a kind of biological treatments which has been known to decrease the organic substance in leachate, accelerate the waste biodegradation process, and increase the volume of biogas generated. This study aims to determine the impact of leachate recirculation on fresh waste and landfill waste toward the quality of leachate effluent, waste degradation rate, and the volume of biogas generated. Therefore, the proper type of waste for leachate recirculation application in landfill site will be discovered. Leachate recirculation was performed using 2 units of bioreactor with leachate recirculation flow rate of $23,4 \mathrm{l} /$ day for 28 days. Leachate is placed on the leachate stock basin to flow into the waste bioreactor within one day. Effluent of leachate from the waste bioreactor then collected in a storage basin before placed back manually into the leachate stock basin. The results show that the BOD and COD value of leachate which was originally $203,38 \mathrm{mg} / \mathrm{l}$ and $986,7 \mathrm{mg} / \mathrm{l}$, at the end of the study dropped to $42,03 \mathrm{mg} / \mathrm{l}$ and 285,7 $\mathrm{mg} / \mathrm{l}$ after recirculated on fresh waste, and dropped to $50,67 \mathrm{mg} / \mathrm{l}$ and $300 \mathrm{mg} / \mathrm{l}$ after recirculated on landfill waste. At the end of the study, removal percentage of $B O D$ and $C O D$ value in the reactor containing fresh waste $(R 1)$ is $79,33 \%$ and $71,04 \%$, while in the reactor containing landfill waste (R2) is $75,09 \%$ and $69,50 \%$. However, the removal percentage of BOD and COD in R2 as big
\end{abstract}


as $72 \%$ and $60 \%$ was done on the first week of the study. The waste degradation rate in $R 1$ is $0,6768 /$ week while in $R 2$ is $0,0784 /$ week. Volume of biogas in $R 1$ started to be measureble on the $14^{\text {th }}$ day until the end of study on $28^{\text {th }}$ day with maximum volume achieved on the last day by 163 $\mathrm{ml}$. Volume of biogas generated in $\mathrm{R} 2$ was not measurable during the study period.

Keywords: leachate recirculation, anaerobic digestion, waste degradation rate

\section{PENDAHULUAN}

TPA (Tempat Pemrosesan Akhir) merupakan tempat pelaksanaan terakhir penanganan sampah yang umum dilakukan di Indonesia (Damanhuri, 2008). TPA Batu Layang, Pontianak merupakan salah satu TPA di Indonesia yang masih beroperasi secara open dumping, yaitu penimbunan sampah perkotaan secara langsung pada landfill tanpa pemilahan terlebih dahulu. Salah satu kelemahan dari sistem open dumping yaitu TPA dengan sistem ini membutuhkan lahan luas, karena memiliki kemampuan reduksi volume sampah secara terbatas (Damanhuri, 2008).

TPA Batu Layang merupakan satu-satunya TPA di Kota Pontianak, telah beroperasi sejak tahun 1997 dan diperkirakan memiliki umur pakai 20 tahun. Timbulan sampah Kota Pontianak pada tahun 2015 adalah 0,52 kg/org/hari dengan komposisi sampah yang didominasi oleh sampah organik dengan presentase $81,4 \%$ dan sampah anorganik 18,6\% (Khatulistiwa, 2016). Dilihat dari banyaknya sampah organik pada TPA, pengolahan secara biologis merupakan jenis pengolahan yang sesuai digunakan sebagai upaya reduksi volume timbunan sampah pada TPA Batu Layang.

Sementara itu, lindi TPA Batu Layang memiliki nilai BOD dan COD berturut-turut sebesar 196 mg/l dan 301 mg/l (Dinas Kebersihan dan Pertamanan Kota Pontianak, 2016). Nilai tersebut melewati baku mutu yang diatur dalam Peraturan Menteri Lingkungan Hidup Republik Indonesia No. 5 Tahun 2014 tentang Baku Mutu Air Limbah. Oleh karena itu, lindi TPA Batu Layang harus diolah terlebih dahulu untuk menurunkan nilai BOD dan COD tersebut sebelum lindi yang dihasilkan oleh TPA Batu Layang dapat dibuang ke badan perairan disekitarnya.

Resirkulasi lindi merupakan salah satu jenis pengolahan biologis yang dilakukan dengan menyemprotkan lindi pada timbunan sampah yang dapat meningkatkan proses biodegradasi sampah dan produksi gas metan $\left(\mathrm{CH}_{4}\right)$, disamping mencegah lindi tersebar keluar ke lingkungan sekitar (Bilgili, et. al., 2007). Resirkulasi lindi dapat mempercepat biodegradasi senyawa organik dalam keadaan anaerobik dan meningkatkan stabilitas dari fase metanogenis pada proses degradasi tersebut (Filipkowska,2007). Sementara itu, pada TPA terdapat sampah segar berupa sampah yang baru masuk ke TPA, maupun sampah lama berupa sampah yang telah berada di sel TPA. Hal ini menimbulkan pemikiran untuk melakukan penelitian lanjutan guna mengetahui jenis sampah yang tepat untuk aplikasi resirkulasi lindi pada TPA khususnya TPA Batu Layang.

Tujuan dari penelitian ini antara lain mengetahui pengaruh resirkulasi lindi pada sampah segar dan sampah TPA terhadap kualitas effluent lindi, mengetahui pengaruh resirkulasi lindi pada sampah segar dan sampah TPA terhadap laju degradasi sampah, dan mengetahui volume biogas yang dihasilkan akibat degradasi sampah segar dan sampah TPA.

\section{METODOLOGI PENELITIAN}

Penelitian dilakukan dalam skala laboratorium menggunakan reaktor sampah berupa tong plastik dengan volume 60 liter. Lindi diresirkulasikan dengan debit 23,4 I/hari. Parameter yang diuji antara lain BOD lindi, COD lindi, pH lindi, dan volume biogas. Kualitas BOD dan COD lindi diuji setiap 7 hari sekali, sedangkan nilai pH lindi, $\mathrm{pH}$ sampah, 
suhu sampah, dan volume biogas diukur setiap hari selama masa penelitian. Penelitian berlangsung selama 4 minggu atau 28 hari.

Penelitian dilakukan dengan mengalirkan lindi ke tumpukan sampah di dalam bioreaktor sampah kemudian meresirkulasikan lindi yang telah melewati sampah tersebut setiap harinya selama masa penelitian. Sebanyak 23,4 I lindi ditempatkan pada bak stok lindi untuk dialirkan ke dalam bioreaktor sampah. Lindi yang keluar dari bioreaktor sampah ditampung pada bak penampung lindi, untuk kemudian ditempatkan kembali pada bak stok lindi secara manual ketika lindi yang berada di bak stok lindi tepat habis. Variabel bebas pada penelitian ini yaitu jenis sampel sampah organik segar (R1) dan sampah organik TPA (R2). Sampel sampah segar berupa sampah domestik sedangkan sampel sampah TPA diambil pada sel A TPA Batu Layang, Pontianak yang telah ditutup sejak tahun 2007. Desain alat yang digunakan disajikan pada Gambar 1.

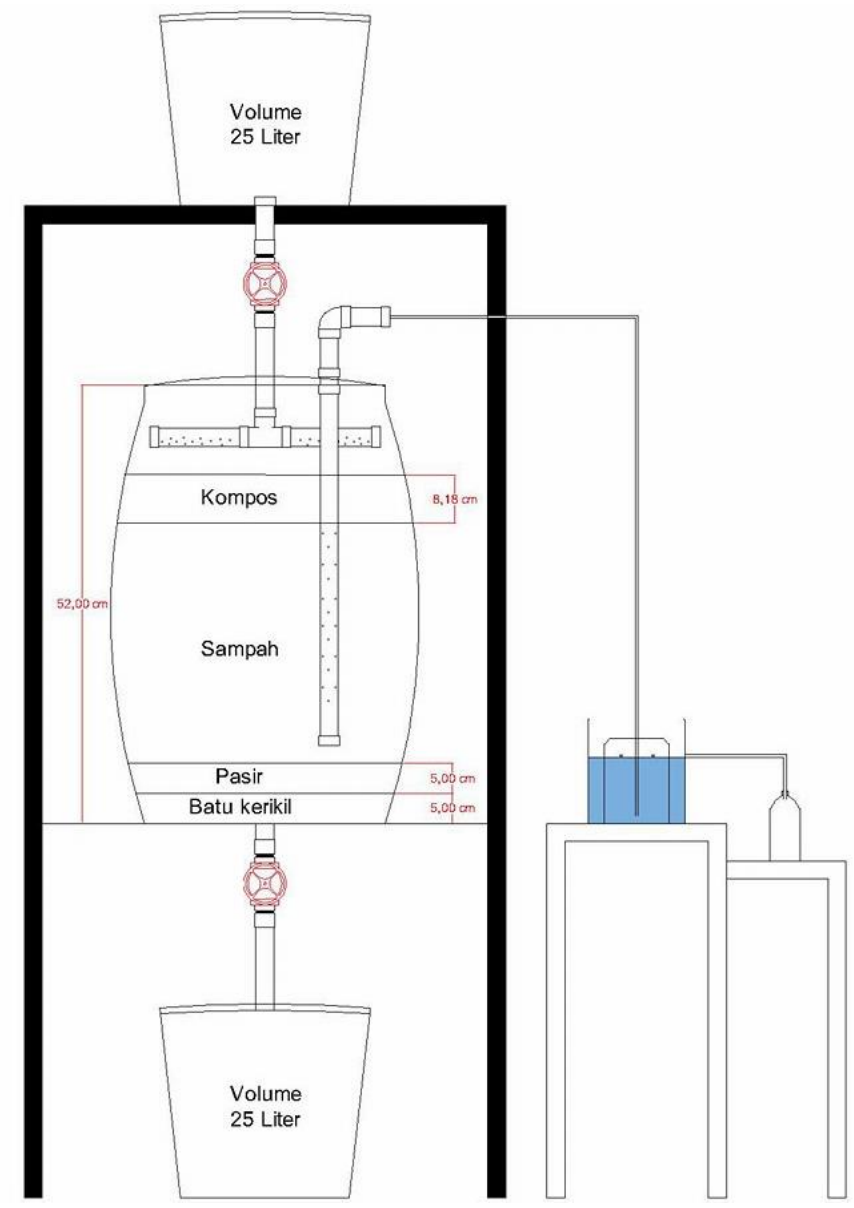

Gambar 1. Desain Bioreaktor Sampah

\section{HASIL DAN PEMBAHASAN}

A. PERUBAHAN NILAI BOD, COD, DAN PH LINDI SELAMA RESIRKULASI LINDI

Pengukuran nilai BOD dan COD lindi dilakukan sebanyak 5 kali. Sampel pertama merupakan sampel lindi TPA yang belum dialirkan kedalam bioreaktor sampah. Sampel ke-2 hingga ke-5 merupakan sampel lindi yang telah dialirkan setiap minggunya pada bioreaktor sampah dan ditampung pada bak outlet lindi. Perubahan nilai BOD dan COD lindi pada bioreaktor sampah berisi sampel sampah segar (R1) dan sampel sampah TPA pada sel A yang telah berumur 9 tahun (R2) selama masa penelitian disajikan pada Tabel 1 dan Tabel 2. 
Tabel 1. Nilai BOD Lindi pada Berbagai Umur Tinggal pada Bioreaktor Sampah

\begin{tabular}{|c|c|c|c|c|c|}
\hline Minggu ke- & 0 & I & II & III & IV \\
\hline BOD R1 (mg/l) & 203,38 & 677,97 & 362,71 & 196,61 & 42,03 \\
\hline BOD R2 (mg/l) & 203,38 & 57,46 & 64,41 & 52,54 & 50,67 \\
\hline
\end{tabular}

Tabel 2. Nilai COD Lindi pada Berbagai Umur Tinggal pada Bioreaktor Sampah

\begin{tabular}{|c|c|c|c|c|c|}
\hline Minggu ke- & 0 & I & II & III & IV \\
\hline COD R1 (mg/L) & 986,7 & 2380,9 & 1266,7 & 842,9 & 285,7 \\
\hline COD R2 (mg/L) & 986,7 & 398,1 & 300,0 & 317,1 & 300,9 \\
\hline
\end{tabular}

Nilai pH lindi harian pada R1 secara umum berada pada jangkauan nilai yang lebih besar yang berada pada fase asam dan basa, dibandingkan dengan $\mathrm{pH}$ lindi pada $\mathrm{R} 2$ yang berada pada fase netral dan basa. Nilai pH lindi harian pada kedua bioreaktor sampah dipaparkan pada Gambar 2.

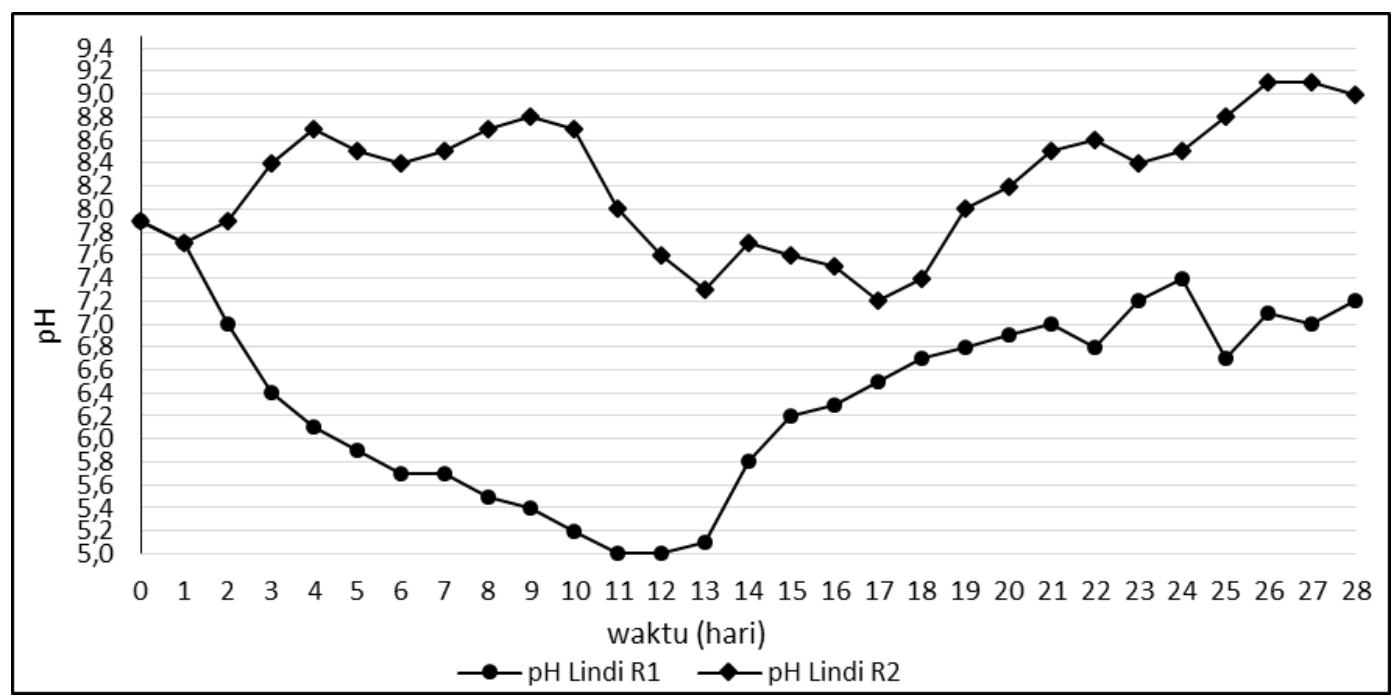

Gambar 2. Grafik perubahan nilai pH lindi terhadap waktu

Pada Tabel 1 dan Tabel 2 terlihat bahwa kadar BOD dan COD lindi pada R1 mengalami kenaikan signifikan di minggu pertama yang diikuti dengan penurunan di minggu-minggu berikutnya. Hal ini berbeda dengan nilai BOD dan COD lindi pada R2 yang mengalami penurunan setiap minggunya. Dari Gambar 2 terlihat bahwa nilai pH lindi harian pada R1 secara umum berada pada jangkauan nilai yang lebih besar dibandingkan $\mathrm{pH}$ lindi pada R2. Perbedaan fluktuasi nilai BOD, COD, dan $\mathrm{pH}$ lindi ini menunjukkan bahwa sampah yang berada di dalam masing-masing reaktor berada pada fase degradasi yang berbeda. Farqurhar (1989) menyebutkan pada penguraian sampah, fase metanogenesis biasanya terjadi pada 5-10 tahun setelah sampah ditempatkan. Fase ini ditandai oleh meningkatnya $\mathrm{pH}$ hingga berkisar diantara $\mathrm{pH} 7-8$, dimana pada fase sebelumnya $\mathrm{pH}$ umumnya berada pada rentang 5-6 serta terjadi peningkatan nilai BOD dan COD. Berdasarkan teori ini maka dapat disimpulkan bahwa selama masa pengoperasian alat, sampah pada R2 yang diambil pada sel A yang telah ditutup sejak tahun 2007 berada pada fase metanogenesis sedangkan sampah pada R1 mengalami penguraian pada beberapa fase degradasi anaerob yang berbeda.

Pada R1, COD lindi pada minggu pertama mengalami kenaikan signifikan. Kenaikan ini menandakan sampah segar telah memasuki fase asidogenesis, karena proses hidrolisis tidak merubah nilai COD (Eckenfelder, 1989). Peningkatan bahan organik yang dinyatakan dengan BOD dan COD lindi diakibatkan larutnya zat organik lemah pada lindi, 
yang terjadi seiringan dengan penurunan $\mathrm{pH}$ lindi. Penurunan $\mathrm{pH}$ lindi pada $\mathrm{R} 1 \mathrm{di}$ Gambar 2 terlihat menurun secara konsisten dari awal proses hingga hari ke-11. Penurunan $\mathrm{pH}$ disebabkan terjadinya proses asidogenesis-asetogenesis. Dalam proses asidogenesis, monomer-monomer hasil proses hidrolisis didegradasi lebih lanjut oleh bakteri asidogenik menjadi asam lemak volatile seperti asam propionat, butirat, valerat, dan sebagian kecil asam asetat, $\mathrm{H}_{2}$, dan $\mathrm{CO}_{2}$ (MetCalf \& Eddy, 2003). Asam-asam organik yang molekulnya lebih berat dari asam asetat akan diubah lebih lanjut oleh bakteri asetogenik pada proses asetogenesis menjadi asam asetat, $\mathrm{H}_{2}$, dan $\mathrm{CO}_{2}$ (Parkin and Owen, 1986), yang menyebabkan pH sampah menurun hingga $\mathrm{pH} 5$ atau lebih rendah lagi (Williams, 2005).

Nilai BOD dan COD sampel lindi R1 di minggu ke 2, 3, dan 4 menunjukkan penurunan yang konsisten, yang menunjukkan bahwa sampah telah memasuki fase metanogenesis. Pada fase ini, terdapat mikroorganisme yang dapat mengkonversi asam asetat fase asam menjadi $\mathrm{CH}_{4}$ (Francois, et. al., 2007). Berkurangnya asam asetat dan senyawa organik menyebabkan kadar BOD dan COD menurun, juga menyebabkan terjadinya peningkatan $\mathrm{pH}$ secara perlahan. Peningkatan $\mathrm{pH}$ secara perlahan disebabkan hasil dekomposisi bahan organik seperti asam organik dikonversikan sebagai metan dan $\mathrm{CO}_{2}$ (Polprasert, 1989).

Berbeda dengan nilai-nilai $\mathrm{pH}$ lindi harian pada R1 yang bersifat asam maupun basa, nilai pH lindi R2 secara keseluruhan berada di kisaran 7,2-9,1, yang menandakan lindi bersifat basa lemah. Nilai pH tidak asam dikarenakan karakteristik sampah TPA yang telah terdegradasi berada pada fase metanogenesis sehingga tidak terjadi pembentukan senyawa asam organik selama resirkulasi lindi berlangsung.

Tidak seperti BOD dan COD lindi R1, kadar BOD dan COD R2 menurun drastis pada minggu pertama kemudian mengalami fluktuasi yang relatif kecil selama pada hasil uji minggu kedua hingga akhir penelitian. Perubahan konsentrasi BOD dan COD yang tidak signifikan pada hasil uji lindi pada minggu ke 2, 3, dan 4 menandakan kandungan organik bio-degradable pada sampah telah habis terdegradasi pada minggu pertama sehingga aktivitas degradasi senyawa organik yang terlihat dari nilai BOD dan COD cenderung stabil. Damanhuri (2008), menyatakan timbunan sampah yang sudah menjadi kompos mampu menurunkan pencemar organik dilihat dari nilai umpan dengan COD \pm 2.500 $\mathrm{mg} / \mathrm{l}$ turun hingga $80 \%$ yang dioperasikan secara anaerobik. Hal ini sesuai dengan hasil penelitian di R2 berupa resirkulasi lindi pada sampah TPA yang telah berbentuk kompos dengan nilai umpan COD lindi $986,7 \mathrm{mg} / \mathrm{l}$ secara anaerobik menghasilkan penurunan sebesar $59,7 \%$ pada minggu pertama dan $69,5 \%$ pada akhir penelitian.

\section{B. PENGARUH RESIRKULASI LINDI TERHADAP KUALITAS LINDI}

Resirkulasi lindi pada sampah segar menyebabkan penurunan nilai BOD dan COD pada lindi sebesar $79,3 \%$ dan $71 \%$ pada akhir penelitian. Sedangkan efektifitas penurunan nilai BOD dan COD pada lindi yang diresikulasikan pada sampah TPA sebesar $75 \%$ dan $69,5 \%$ pada akhir penelitian. Namun efisiensi penurunan BOD sebesar $71,7 \%$ dan penurunan COD sebesar $59,6 \%$ dari efisiensi penurunan selama penelitian terjadi pada minggu pertama perlakuan resirkulasi lindi. Pada minggu-minggu selanjutnya, efisiensi penurunan BOD dan COD relatif stabil dengan adanya peningkatan dan penurunan yang masih mendekati nilai BOD dan COD dari minggu sebelumnya.

Scott, et. al. (1994) dalam Ngo, et. al. (2008) menjelaskan bahwa terdapat dua jenis strategi pengolahan lindi yang umum digunakan oleh TPA modern, yaitu resirkulasi lindi dan single pass leaching. Resirkulasi lindi sesuai untuk landfill yang berada di lokasi tropis yang memiliki curah hujan yang rendah, dimana kelebihan dari metode ini yaitu operasinya yang mudah dan biaya operasi yang rendah. Sedangkan metode single pass 
leaching diterapkan oleh landfill pada umumnya dimana lindi yang dihasilkan dikumpulkan dan diolah terlebih dahulu untuk menghilangkan sebagian besar kontaminannya sebelum dialirkan ke badan air penerimanya.

Resirkulasi lindi juga dapat mempercepat stabilisasi landfill, yang ditandai dengan komposisi dan kualitas effluent lindi yang relatif stabil dari waktu ke waktu. Pada R1, nilai BOD dan COD lindi terus berubah dari minggu ke minggu. Sedangkan pada R2 nilai BOD dan COD lindi telah stabil di minggu pertama yang terlihat dari perubahan nilai BOD dan COD lindi di minggu kedua, ketiga, dan keempat yang tidak signifikan. Hal ini mengindikasikan bahwa sampah segar belum stabil sedangkan sampah TPA telah stabil setelah diresirkulasi dengan lindi selama satu minggu. Oleh karena itu, dilihat dari tingkat stabilitas sampah, sampah segar lebih membutuhkan perlakuan resirkulasi lindi dibanding sampah TPA.

Berdasarkan persentase penurunan kadar BOD dan COD lindi mingguan pada R1 maupun R2, dapat disimpulkan bahwa perlakuan resirkulasi lindi pada sampah TPA cenderung tergolong dalam metode pengolahan lindi berupa single pass leaching dibanding metode resirkulasi lindi, karena besarnya efektifitas penurunan BOD dan COD yang didapat pada minggu pertama sedangkan diminggu berikutnya persentase penurunan yang dicapai sedikit. Dalam kata lain, pada penerapan di TPA, sampah segar lebih tepat mendapat perlakuan resirkulasi lindi guna mempercepat stabilisasi sampah dan menurunkan kadar BOD dan COD lindi, sedangkan sampah TPA lebih tepat mendapat perlakuan berupa dialirkan dengan lindi/single pass leaching karena dapat menurunkan kadar BOD dan COD lindi yang melewatinya.

Konsentrasi BOD dan COD lindi pada R2 yang relatif konstan pada hasil uji BOD minggu 1,2, 3 dan 4 diakibatkan oleh biodegradibilitas sampah TPA yang rendah. Rasio BOD/COD lindi pada sampah TPA lebih rendah dibandingkan rasio BOD/COD dari lindi sampah segar. Rasio BOD/COD dapat digunakan untuk menggambarkan tingkat biodegradibilitas pada lindi serta umur dari landfill. Rasio BOD/COD yang rendah menunjukkan sulitnya sampah tersebut untuk terdegradasi secara biologis akibat rendahnya senyawa organik yang bio-degradable.

Rasio BOD/COD dari kedua jenis lindi yang dialirkan pada sampah segar maupun sampah TPA menunjukkan penurunan rasio BOD/COD pada akhir masa penelitian, yaitu sebesar 0,147 pada R1 dan 0,168 pada R2. Turunnya rasio BOD/COD diakibatkan bahwa kadar senyawa organik yang dapat didegradasi secara biologis pada lindi telah berkurang dengan adanya resirkulasi lindi baik pada sampah segar maupun sampah TPA. Rasio BOD/COD pada kedua jenis lindi disajikan pada Tabel 3.

Tabel 3 Perubahan Rasio BOD/COD Lindi Berdasarkan Waktu

\begin{tabular}{|c|c|c|c|c|c|}
\hline Minggu & 0 & 1 & 2 & 3 & 4 \\
\hline Sampah Segar & 0,206 & 0,285 & 0,286 & 0,233 & 0,147 \\
\hline Sampah TPA & 0,206 & 0,144 & 0,215 & 0,166 & 0,168 \\
\hline
\end{tabular}

Tabel 3 menunjukkan bahwa rasio BOD/COD minimum pada R1 berada pada waktu yang berbeda. Pada R1 rasio minimum terjadi pada minggu ke-4 dengan nilai 0,147 sedangkan pada $\mathrm{R} 2$ rasio $\mathrm{BOD} / \mathrm{COD}$ minimum terjadi pada minggu ke-1 dengan nilai 0,144 . Rasio BOD/COD lindi yang telah mendekati 0,1 menandakan karakteristik untuk lindi yang telah stabil (Granet, 1986 dalam Bhalla, 2013).

Selain berdasarkan rasio BOD/COD pada akhir masa penelitian, nilai pH lindi pada R1 maupun R2 juga terindikasi telah stabil dilihat dari nilai pHnya. Nilai pH lindi R1 meningkat hingga $\mathrm{pH}$ 7,2 pada akhir pengoperasian serta nilai $\mathrm{pH}$ lindi $\mathrm{R} 2$ yang berkisar antara 7,2-9,1 selama penelitian. Menurut Granet (1986) dalam Bhalla (2013) lindi yang 
telah stabil memiliki kisaran nilai $\mathrm{pH}$ 8. Pada $\mathrm{pH}$ ini konsentrasi dari ion logam pada lindi secara umum rendah karena penurunan kelarutan dari ion logam yang terjadi seiring dengan meningkatnya $\mathrm{pH}$.

\section{PENGARUH RESIRKULASI LINDI TERHADAP LAJU DEGRADASI SAMPAH}

Degradasi nilai COD lindi untuk menggambarkan laju degradasi sampah dinyatakan dengan nilai $\mathrm{k}$ pada persamaan kinetik laju degradasi orde kesatu. Persamaan laju degradasi sampah didapatkan dengan pengeplottan grafik menggunakan Software Microsoft Excel dengan data nilai absis (sumbu x) berupa lama degradasi dalam satuan minggu, dan nilai -In Se/So sebagai nilai ordinat (sumbu y). Selain nilai k, diketahui nilai $\mathrm{R}^{2}$ yang menggambarkan ketepatan persamaan laju degradasi yang didapatkan. Persamaan laju degradasi sampah pada R1 dan R2 disajikan pada Gambar 3.

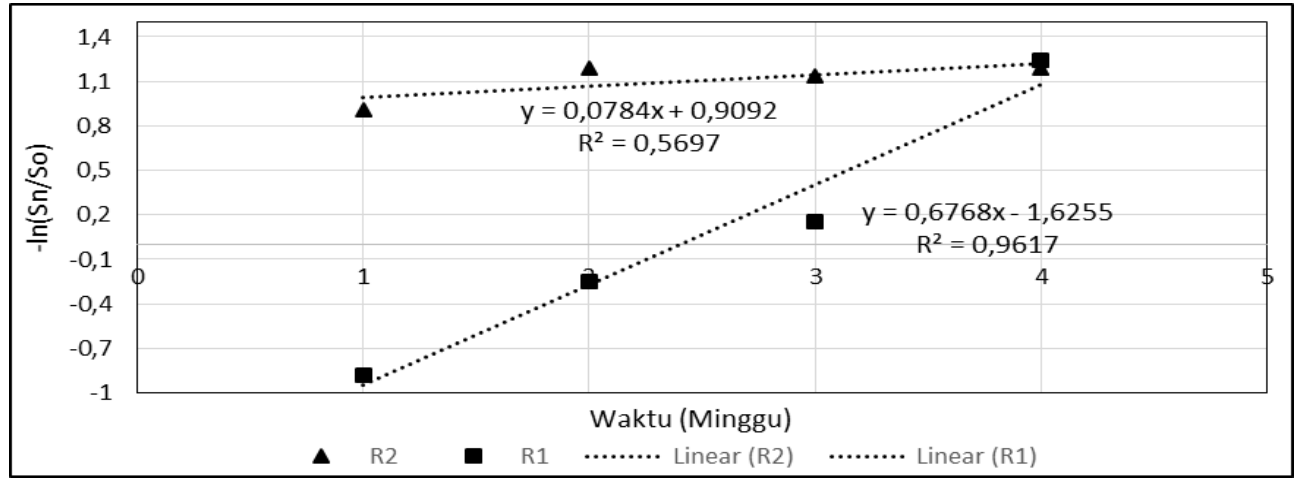

Gambar 3. Grafik persamaan kinetik orde kesatu laju degradasi sampah

Berdasarkan Gambar 3, laju degradasi sampah pada R1 berlangsung lebih cepat dibandingkan laju degradasi sampah pada R2 yang terlihat dari nilai k pada R1 yang lebih besar dibandingkan dengan nilai $k$ dari R2. Nilai k pada R1 yaitu sebesar 0,6768 minggu $^{-1}$ sedangkan nilai $k$ pada R2 yaitu sebesar 0,0784 minggu $^{-1}$. Nilai ini menunjukkan konsentrasi COD lindi yang menggambarkan laju degradasi pada R1 mengalami penurunan sebesar 0,6768 kali dari nilai COD lindi diminggu sebelumnya setelah diresirkulasikan selama satu minggu, sedangkan pada R2 nilai COD lindi turun sebesar 0,0784 kali dari nilai nilai COD lindi diminggu sebelumnya setelah diresirkulasikan selama satu minggu. Nilai laju degradasi pada R1 yang lebih besar dibandingkan dengan nilai pada R2 diakibatkan oleh penurunan COD lindi yang terjadi pada R1 lebih konsisten menurun dengan selisih penurunan yang lebih teratur dibandingkan pada R2.

Selain nilai $k$, diketahui nilai $R^{2}$ pada $R 1$ sebesar 0,9617 sedangkan nilai $R^{2}$ pada $R 2$ yaitu sebesar 0,5697. Nilai $R^{2}$ pada $R 1$ yang lebih besar dibandingkan pada $R 2$ mengindikasikan bahwa tingkat ketepatan persamaan laju degradasi pada R1 lebih tinggi dibandingkan R2. Hal ini disebabkan oleh penurunan nilai COD lindi pada R1 yang lebih konsisten setiap minggunya dibandingkan dengan penurunan nilai COD lindi pada R2.

Sampah segar yang muda memiliki kandungan organik yang lebih tinggi dibandingkan sampah tua (Kasam, 2015). Perbedaan kandungan organik sampah di bioreaktor menyebabkan perbedaan nilai laju degradasi pada kedua bioreaktor tersebut. Hal ini disebabkan oleh substrat organik pada R1 lebih banyak tersedia dibanding didalam R2. Adanya ketersediaan bahan-bahan organik yang cukup besar di R1 mendorong mikroba-mikroba berkembang lebih tinggi, dengan demikian secara total konversi substrat menjadi lebih tinggi. Sebaliknya, di R2 ketersediaan bahan-bahan organik dalam limbah cair lebih sedikit karena sebagian besar telah terdegradasi selama 
berada di TPA. Akibatnya, laju pertumbuhan mikroorganisme baik di dalam R2 lebih rendah akibat konversi kandungan COD terhadap COD influen lebih kecil (Husin, 2008).

\section{PENGARUH RESIRKULASI LINDI TERHADAP VOLUME BIOGAS YANG DIHASILKAN}

Pengukuran volume biogas dilakukan dengan mengukur volume air yang terdesak akibat volume biogas pada wadah berisi air kedalam botol. Pada R1, botol mulai terisi air pada hari ke-14 hingga akhir penelitian. Sedangkan pada R2 tidak terdapat air yang tertampung pada botol selama masa pengoperasian alat. Hasil pengukuran volume biogas pada kedua reaktor disajikan pada Gambar 4.

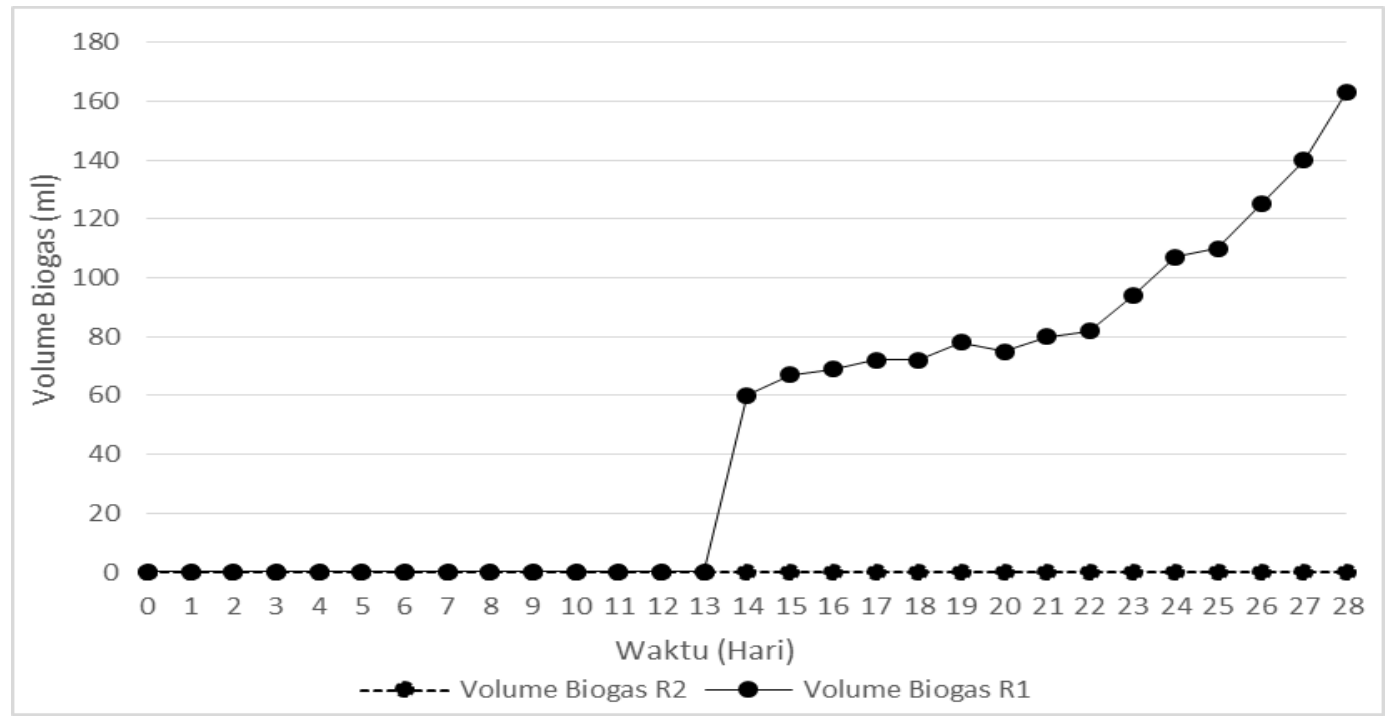

Gambar 4. Produksi biogas pada kedua bioreaktor sampah

Pada Gambar 4 terlihat bahwa pada R1 terbentuk biogas yang dimulai pada hari ke-13 hingga hari ke-28, sedangkan produksi biogas pada R2 tidak terukur selama masa pengoperasian. Pada R1, biogas terbentuk pada hari ke-14. Pada waktu ini sampah telah berada pada fase metanogenesis yang menghasilkan biogas berupa $\mathrm{CH}_{4}$, dan $\mathrm{CO}_{2}$ sebagai produknya. Pembentukan biogas pada hari ke-14 ini konsisten dengan hasil pengukuran $\mathrm{pH}$ lindi yang nilainya mulai meningkat masing-masing pada hari ke-13 yang dapat dilihat pada Gambar 2. Proses peningkatan volume biogas yang terbentuk secara perlahan menandakan fase metanogenesis (fase pembentukan gas) telah dimulai (Aljaradin and Persson, 2016).

Tidak terbentuknya biogas pada awal pengoperasian hingga pada hari ke-13 disebabkan karena pada rentang waktu tersebut sampah segar mengalami fase hidrolisis, asidogenesis, dan kemudian asetogenesis, dimana pada ketiga tahap awal ini proses yang berlangsung tidak menghasilkan biogas sebagai produknya. Produksi biogas kemudian secara stabil meningkat hingga pada akhir pengoperasian alat. Produksi biogas tidak mengalami penurunan volume yang tinggi menandakan bahwa fase metanogensesis belum selesai (Vaidya, 2002).

Produksi biogas pada reaktor berisi sampah segar dengan perlakuan resirkulasi lindi juga dilakukan oleh Agustina (2012). Pada penelitian tersebut dilakukan resirkulasi lindi dengan umpan COD lindi awal sebesar $4.640 \mathrm{mg} / \mathrm{l}$ pada beberapa bioreaktor berisi sampah segar organik dengan variasi debit resirkulasi lindi dan variasi debit penambahan bioaktivator organodegra (Agustina,2012). Reaktor kontrol pada penelitian Agustina (2012) dengan debit resirkulasi $480 \mathrm{ml} / \mathrm{menit}$ selama 30 menit/hari tanpa penambahan bioaktivator selama 30 hari pengoperasian. Produksi biogas pada reaktor 
kontrol tersebut menghasilkan biogas dengan volume $\pm 520 \mathrm{ml}$ pada akhir penelitian. Nilai COD awal pada resirkulasi lindi dan volume biogas yang dihasilkan sebanding dengan hasil produksi biogas pada R1 dengan umpan COD lindi awal sebesar 986,7 mg/l yang menghasilkan biogas sebesar $163 \mathrm{ml}$ di akhir pengoperasian yaitu pada hari ke-28.

Tidak seperti reaktor R1 yang menghasilkan biogas, reaktor R2 tidak menghasilkan biogas hingga akhir masa pengoperasian. Hal ini dapat disebabkan oleh kurangnya bahan organik yang bersifat bio-degradable pada R2 setelah minggu ke-2 resirkulasi yang terlihat dari konsentrasi BOD dan COD lindi R2 yang stabil pada minggu ke-2, ke-3, dan ke-4. Habisnya bahan organik bio-degradable pada sampah menyebabkan konversi asam asetat, $\mathrm{H}_{2}$, dan $\mathrm{CO}_{2}$ menjadi biogas tidak dapat berlangsung.

\section{KESIMPULAN}

Adapun simpulan yang dapat dipaparkan antara lain:

1. Kualitas lindi dilihat dari parameter BOD dan COD mengalami perbaikan setelah diresirkulasikan pada sampah segar maupun sampah TPA. Nilai BOD dan COD lindi yang semula $203,38 \mathrm{mg} / \mathrm{l}$ dan $986,7 \mathrm{mg} / \mathrm{I}$ pada akhir masa penelitian turun menjadi $42,03 \mathrm{mg} / \mathrm{l}$ dan $285,7 \mathrm{mg} / \mathrm{l}$ setelah diresirkulasi pada sampah segar, dan turun menjadi 50,67 mg/l dan $300 \mathrm{mg} / \mathrm{l}$ setelah diresirkulasikan pada sampah TPA. Pada akhir penelitian, efisiensi penurunan nilai BOD dan COD pada reaktor berisi sampah segar (R1) sebesar 79,3\% dan 71\% sedangkan pada reaktor berisi sampah TPA (R2) sebesar $75,1 \%$ dan $69,5 \%$. Namun, penurunan BOD dan COD lindi pada R2 sebesar $72 \%$ dan $60 \%$ terjadi pada minggu pertama perlakuan resirkulasi lindi.

2. Laju degradasi sampah yang dihitung dengan menggunakan persamaan kinetik laju degradasi orde kesatu pada R1 sebesar 0,6768/minggu sedangkan pada R2 sebesar 0,0784 /minggu.

3. Produksi biogas akibat degradasi anaerob yang terjadi pada R1 mulai terukur pada hari ke-14 hingga akhir penelitian pada hari ke-28 dengan volume maksimum dicapai pada hari terakhir penilitian yaitu sebesar $163 \mathrm{ml}$. Sedangkan pada R2 volume biogas yang dihasilkan tidak terukur selama pengoperasian alat berlangsung.

\section{UCAPAN TERIMA KASIH}

Terima kasih kepada dosen pembimbing skripsi, Ibu Isna Apriani dan Ibu Ulli Kadaria serta dosen penguji skripsi, Ibu Yulisa Fitrianingsih dan Bapak Hendri Sutrisno, Pihak UPTD TPA Batu Layang Kota Pontianak, serta semua pihak yang terlibat dan membantu penulis selama proses pengerjaan penelitian yang tidak dapat diucapkan satu persatu.

\section{DAFTAR PUSTAKA}

Agustina, U. A. 2012. Pengaruh Resirkulasi Lindi Terhadap Laju Degradasi Sampah di TPA Ngipik, Gresik. Surabaya: Teknik Lingkungan Institut Teknologi Sepuluh November.

Aljaradin, M., and Persson., K. M. 2016. The Emission Potential From Municipal Solid Waste Landfill in Jordan. Research Article. Jurnal of Ecological Engineering. Volume 17 Issue 1.

Bhalla, B. 2013. Effect of Age and Seasonal Variations on Leachate Characteristics of Municipal Solid Waste Landfill. IJRET: International Journal of Research in Engineering and Technology. Volume: 02 Issue: 08. http://www.ijret.org

Bilgili, M.; Demir, A.; dan Ozkaya, B. 2007. Influence of Leachate Recirculation on Aerobic and Anaerobic Decomposition of Solid Wastes. Journal of Hazardous Material. 
Damanhuri, E. 2008. Diktat Landfilling Limbah. Bandung: Fakultas Teknik Sipil dan Lingkungan ITB.

Dinas Kebersihan dan Pertamanan Kota Pontianak. 2016. Laporan Hasil Uji (LHU) Air Limbah Bagi Usaha dan/atau Kegiatan yang Belum Memiliki Baku Mutu Air Limbah yang Ditetapkan. Pontianak: Laboratorium Penguji Pemerintah Provinsi Kalimantan Barat.

Eckenfelder, W.W. 1989. Industrial Water Pollution Control. $2^{\text {nd }}$ Ed. New York: Mc-Graw Hill Inc.

Farquhar, G. J. 1989. Leachate: Production and Characterization. Canadian Journal of Civil Engineering.

Filipkowska, U. 2007. Effect of Recirculation Method on Quality of Landfill Leachate and Effectiveness of Biogas Production. Original Research. Poulish Journal of Environmental Study. Volume 17 No. 2.

Francois, V.; Feuillade, G.; Matejka, G.; Lagier, T.; and Skhiri, N. 2007. Leachate Recirculation Effects on Waste Degradation: Study on Columns. Waste Management.

Husin, A. 2008. Pengolahan Limbah Cair Industri Tahu dengan Biofiltrasi Anaerob dalam Reaktor Fixed - Bed. Tesis. Medan: Sekolah Pasca Sarjana Universitas Sumatera Utara.

Kasam. 2015. Dinamika Lindi Sampah Perkotaan Pasca Penutupan Tempat Pembuangan Akhir (TPA). Disertasi. Yogyakarta: Universitas Gadjah Mada.

Kementerian Lingkungan Hidup RI. 2014. Peraturan Menteri Lingkungan Hidup Republik Indonesia Nomor 5 Tahun 2014 Tentang Baku Mutu Air Limbah. Jakarta.

Khatulistiwa, M. R., 2016. Inventarisasi Emisi CH4 di TPA Batu Layang Kota Pontianak Provinsi Kalimantan Barat. Skripsi. Pontianak: Teknik Lingkungan Universitas Tanjungpura.

Metcalf \& Eddy. 2003. Wastewater Engineering: Treatment, Disposal, and Reuse. 4th Ed. Singapore: McGraw-Hill.

Ngo, H.H.; Guo, W.S.; dan Xing, W. 2008. Applied Technologies in Municipal Solid Waste Landfill Leachate Treatment. Encyclopedia of life support systems. EOLSS

Parkin, G. F., and Owen, W. E. 1986. Fundamentals of Anaerobic Disgestion of Wastewater Sludge.

Polprasert, C. 1989. Organic Waste Recycling. Inc. Indonesia

Vaidya, R.D. 2002. Solid Waste Degradation, Compaction and Water Holding Capacity. Thesis. Virginia. Faculty of the Virginia Polytechnic Institute and State University.

Williams, P. T. 2005. Waste Treatment and Disposal. England: John Wiley and Sons, Ltd. 